\title{
Bioremediation of endosulfan in laboratory-scale constructed wetlands: effect of bioaugmentation and biostimulation
}

\author{
Congcong Zhao ${ }^{1}$, HuiJun $\mathrm{Xie}^{2}$, Yang $\mathrm{Mu}^{6}$, Xiaoli Xu ${ }^{1}$, Jian Zhang ${ }^{1}$, Cui Liu ${ }^{3}$, Shuang Liang ${ }^{1}$, \\ Huu Hao Ngo ${ }^{4}$, Wenshan Guo ${ }^{4}$ Jingtao $\mathrm{Xu}^{5}$ and Qian Wang ${ }^{1}$ \\ ${ }^{1}$ School of Environmental Science and Engineering, Shandong University, Jinan, 250100, China \\ ${ }^{2}$ Environment Research Institute, Shandong University, Jinan, 250100, China \\ ${ }^{3}$ Department of Mathematics and Statistics, Texas Tech University, Broadway and Boston, Lubbock, TX 79409- \\ 1042, USA \\ ${ }^{4}$ School of Civil and Environmental Engineering, University of Technology Sydney, Broadway, Ultimo, NSW, \\ 2007, Australia \\ ${ }^{5}$ School of Municipal and Environmental Engineering, Shandong Jianzhu University, Jinan, 250101, China \\ ${ }^{6}$ School of Environmental and Municipal Engineering, Qingdao Technological University, Qingdao, 266520, \\ China \\ *Corresponding author, Jian Zhang Email: zhangjianoo@sdu.edu.cn
}

\begin{abstract}
Bioremediation is widely used in organic pollutants disposal. However, very little has been known on its application in constructed wetlands contaminated with organochlorine pesticide, endosulfan in particular. To evaluate the effect of bioremediation on endosulfan removal and clarify the fate, bioaugmentation and biostimulation were studied in laboratory-scale verticalflow constructed wetlands. After 20 days' experiment, endosulfan isomers removal efficiencies were increased to $89.24-97.62 \%$ through bioremediation. In bacteria bioaugmentation (E-in) and sucrose biostimulation (E-C), peak concentrations of endosulfan in sediment were reduced by $31.02-76.77 \%$, and plant absorption were $347.45-$ $576.65 \mu \mathrm{g} \mathrm{kg}^{-1}$. By contrast, plant absorption in $\mathrm{KH}_{2} \mathrm{PO}_{4}$ biostimulation (E-P) was increased to 811.64 and $1,067.68 \mu \mathrm{g} \mathrm{kg}^{-1}$. Degradation process was probably promoted in E-in and E-C,
\end{abstract}


while plant absorption was enhanced in E-P. Consequently, E-in and E-C were effective for endosulfan removal in constructed wetlands, while adding $\mathrm{KH}_{2} \mathrm{PO}_{4}$ had potential to cause air pollution. Additionally, combined bioremediation was not recommended.

Keywords: Bioremediation; Constructed wetlands; Endosulfan; Sucrose; $\mathrm{KH}_{2} \mathrm{PO}_{4}$

\section{Introduction}

Since the 1950s, endosulfan is one kind of organochlorine pesticide commonly used in agriculture to control a wide range of pests for crops, including cotton, rice, sorghum, and soy (Jia et al. 2010). It causes worldwide concerns due to its environmentally persistent and semivolatile characters. Endosulfan can particularly accumulate in organism and cause neurotoxicity (Silva and Beauvais 2010). Although endosulfan has been banned in many countries, it still exists on the list of allowable insecticides in China on certain crops (Zhang et al. 2012). According to a report by United Nations Environment Programme (UNEP), China ranked third on the list of endosulfan production, and the annual production was 4,602 , 5,003 and 5,177 tons for 2006, 2007, and 2008, respectively (UNEP 2010). Moreover, endosulfan isomers are ubiquitous in Chinese surface soil with the occurrence frequencies of 83 and $96 \%$, respectively (Jia et al. 2010). Thus, effective control over endosulfan pollution is necessary.

Wetland treatment is a sustainable and economical technology that can be an alternative to conventional wastewater treatment. One type of constructed wetland, the vertical-flow constructed wetland is now popular in some specific cases for the small surface requirement and high purification efficiency of organic matter, like pesticide (Cheng et al. 2002; Wu et al. 2013). However, organochlorine pesticides are persistent organic pollutant, and thus their 
concentrations in wetland effluents were usually higher than the thresholds (Cheng et al. 2002; Gregoire et al. 2009). Therefore, there is still a need for optimizing the operational efficiency.

Using the strategy of bioremediation (bioaugmentation and biostimulation), removal of organic pollutants in wetlands can be promoted (Santos et al. 2011). Bioaugmentation is adding pre-adaptive catabolic bacteria to the target environment. Biostimulation is achieved by supplying nutrients $(\mathrm{C}, \mathrm{N}$, or $\mathrm{P}$ ) or suitable conditions (available oxygen, temperature, $\mathrm{pH}$, and redox potential) to stimulate indigenous microorganisms (Garcia-Blanco et al. 2007). Although extensive works have been carried out on the bioremediation of organic pollutants in soil (Beolchini et al. 2010; Didier et al. 2012), little has been done for constructed wetlands contaminated with pesticide, particularly endosulfan.

Moreover, bioaugmentation and biostimulation are controversial technologies. Although some researches demonstrated their effectiveness in contamination removal, while others doubted. The survival of extra-adding microbe is threatened by both abiotic and biotic conditions, and their potential to become invasive microbe or impact on the local ecology remains unknown (Filler et al. 2009). The applied nutrients do not always work either (Yu et al. 2011). As constructed wetland is a complex system functioning with the interaction of water, sediment, plants, and microorganisms, whether bioaugmentation and biostimulation can be used to optimize pesticide removal and the certain fate of pesticide during the treatment are of essential needs to study.

As an initial attempt, the effects of bioaugmentation and biostimulation on endosulfan removal in laboratory-scale vertical-flow constructed wetlands were evaluated in this study. Endosulfan degradation bacteria were applied in bioaugmentation. Additional sucrose 
and $\mathrm{KH}_{2} \mathrm{PO}_{4}$ was designed to cause biostimulation process, as a former study has revealed that organic matter and phosphorus were important factors to the distribution of endosulfan in soil (Zhao et al. 2013). In addition, a further evaluation was constructed by combination of bioaugmentation and biostimulation. The fate of endosulfan and underlying mechanisms were analyzed and elucidated. In addition, the combination of bioaugmentation and biostimulation was also tested for a more comprehensive understanding. This work provides useful information on the feasibility of bioremediation in constructed wetlands.

\section{Material and methods}

Materials

\section{Plants and chemicals}

Sprouted Phragmites australis of 15- to 20-cm height were collected from Nansi Lake in March and moved into laboratory-scale vertical-flow constructed wetland systems immediately and cultivated in Hoagland solution (10\%) for the first month.

Technical-grade endosulfan was used in the laboratory-scale experiment and standard endosulfan isomers (Sigma-Aldrich, USA) were used for chromatography analysis.

\section{Laboratory-scale batch-operated vertical-flow constructed wetlands}

Polyethylene barrels ( $23 \mathrm{~cm}$ in inner diameter, $50 \mathrm{~cm}$ in height) were used to build laboratory-scale batch-operated vertical-flow constructed wetlands as Prochaska and Zouboulis (2006) described. Each wetland was filled with two layers of substrate in the barrel. The bottle layer was $10 \mathrm{~cm}$ in height and was made up of washed gravel (1-3 cm in diameter), while the upper layer is $35 \mathrm{~cm}$ in height, using washed sand $(0-3 \mathrm{~mm}$ in diameter, mainly $\mathrm{Si}_{2} \mathrm{O}_{3}, \mathrm{Al}_{2} \mathrm{O}_{3}$, and $\mathrm{Fe}_{2} \mathrm{O}_{3}$ ) as substrate. A vertical-perforated PVC pipe (3 cm in diameter, 
$50 \mathrm{~cm}$ in height) was inserted to the middle of substrate in each barrel to measure physical and chemical parameters in situ. Pre-punched polyethylene tubes were buried in the barrel for ventilation, and a stopper was set at the bottom of each barrel to collect the effluents. $P$. australis density was about six plants per barrels in the constructed wetland systems.

These constructed wetlands were located in the Baihua Park of Jinan, China, with a

hydraulic load of $0.108 \mathrm{~m}^{3} \mathrm{~m}^{-2}$ batch $^{-1}$, an average porosity of $26.85 \%$, and HRT of 20 days.

Methods

Inoculums degradation characters and their preparation

Endosulfan-degrading bacteria were isolated from the polluted soil in a pesticide factory using the method described by Kalyani et al. (2009). The DNA was extracted using MOBIO PowerSand ${ }^{\mathrm{TM}}$ DNA Isolation Kit. Further purification and sequence test was accomplished by Sangon Biotech Company (Shanghai, China). Basic Local Alignment Search Tool (BLAST) was used to identify DNA sequence according to the National Center for Biotechnology Information (NCBI) database.

Selected strains were inoculated into the surfer-free cultural medium with $100 \mu \mathrm{g} \mathrm{mL} \mathrm{L}^{-1}$ of endosulfan at $28^{\circ} \mathrm{C}$ for 14 days to study the degrading abilities in cultural medium (Kalyani et al. 2009). Purified strains grew overnight in sterilized nutrient broth on a shaker at $28^{\circ} \mathrm{C}$, and then harvested at late log phase by centrifugation $(12,000 \times g, 10 \mathrm{~min})$. The pellets were washed twice then dissolved in sterile distilled water to similar concentration. A mixed inoculums, which had volume equal to each bacterial strain suspensions, were adjusted to an attendance of 0.5 at $600 \mathrm{~nm}$ by sterile distilled water 
(equivalent to approximately $7.4 \times 10^{8} \mathrm{cfu} \mathrm{mL}^{-1}$ ), for bioremediation experiment (Abou-

Shanab et al. 2008).

\section{Experimental procedures}

From April 2012 to August 2012, synthetic wastewater was used to cultivate P. australis. The synthetic wastewater was mainly composed of sucrose, $\left(\mathrm{NH}_{4}\right)_{2} \mathrm{SO}_{4}, \mathrm{KH}_{2} \mathrm{PO}_{4}$, and $\mathrm{KNO}_{3}$, with some micronutrients for the normal growth and development of the plant $\left(\mathrm{mg} \mathrm{L}^{-1}\right): 21 \mathrm{Ca}$, $10 \mathrm{Mg}, 14 \mathrm{~S}, 0.8 \mathrm{P}, 0.3 \mathrm{Fe}, 0.03 \mathrm{Zn}, 0.01 \mathrm{Cu}, 0.03 \mathrm{Mn}, 0.03 \mathrm{~B}$, and 0.002Mo (Wu et al. 2011a). The characters of the influence water were as follows $\left(\mathrm{mg} \mathrm{L}^{-1}\right)$ : COD, $61.2 \pm 2.6$; total nitrogen $(\mathrm{TN}), 19.1 \pm 1.3$; ammonium $\left(\mathrm{NH}_{4}-\mathrm{N}\right), 8.3 \pm 0.5 ; \mathrm{TP}, 1.5 \pm 0.2 ; \mathrm{pH}, 7.16 \pm 0.21$.

Eighteen constructed wetlands with similar growth conditions of plant were chosen for further experiment. These wetlands, divided into six groups, were designed (Table 1) to study three kinds of treatments (bioaugmentation, biostimulation, and combination of them). Endosulfan $\left(100 \mu \mathrm{g} \mathrm{L} \mathrm{L}^{-1}\right)$ was added to the synthetic wastewater of these systems.

Table 1

Tested bioremediation treatments in constructed wetland systems

\begin{tabular}{llllll}
\hline & Bioaugmentation & \multicolumn{2}{c}{ Biostimulation } & \multicolumn{2}{c}{ Mixed bioremediation } \\
\cline { 2 - 6 } & E-in & E-C & E-P & E-in-C & E-in-P \\
\hline \multirow{2}{*}{ Control } & Mixed inocula & Sucrose $^{\mathrm{b}}$ & $\mathrm{KH}_{2} \mathrm{PO}_{4}{ }^{\mathrm{c}}$ & $\begin{array}{l}\text { Mixed } \\
\text { inocula } \\
\text { sucrose }\end{array}$ & $\begin{array}{l}\text { Mixed } \\
\text { inocula }^{\mathrm{a}}+ \\
\mathrm{KH}_{2} \mathrm{PO}_{4}{ }^{\mathrm{c}}\end{array}$ \\
\hline
\end{tabular}

Endosulfan was added at the beginning of the treatment (final concentration of $100 \mu \mathrm{g} \mathrm{L}^{-1}$ ), and all treatments were replicated three times

${ }^{a}$ Mixed inocula of $50 \mathrm{~mL}$ were added

${ }^{\mathrm{b}}$ The final concentration of sucrose was $240 \mathrm{mg} \mathrm{L}^{-1}$

${ }^{\mathrm{c}}$ The final concentration of $\mathrm{KH}_{2} \mathrm{PO}_{4}$ was $35 \mathrm{mg} \mathrm{L}{ }^{-1}$

Bioaugmentation (E-in) was conducted by adding mixed inocula of endosulfandegrading bacteria (50 $\mathrm{mL}$; prepared according to "Inoculums degradation characters and 
their preparation”). Additional sucrose and $\mathrm{KH}_{2} \mathrm{PO}_{4}$ was used (E-C and E-P) in biostimulation process. A combination of bioaugmentation and biostimulation (namely E-inC and E-in-P) was constructed further. All treatments were replicated three times, and the temperature was from 22 to $32{ }^{\circ} \mathrm{C}$ during the treatment.

\section{Sampling and sample processing}

Water and sediment samples were taken on $0,1,3,6,12$, and 20 days. Considering the slow absorption of pesticide in plants as well as reducing the injury to plants, leaves samples were harvested only at day 12 and 20 . Water samples $(100 \mathrm{~mL})$ were homogenized and collected in polyethylene plastic bottles. Sediment samples were taken from the same height, and five individuals with equal amounts were homogenized to obtain a representative sample for each barrel. Sediment samples were kept in the sterilized centrifuge tubes $(5 \mathrm{~g})$ and polyethylene plastic bags $(25 \mathrm{~g})$. Leaves samples $(5 \mathrm{~g})$ within the similar growth period were collected and then stored in sealed bags.

Samples were transported to the laboratory in a chilled insulating box. Water samples were kept at $4{ }^{\circ} \mathrm{C}$ and examined within $24 \mathrm{~h}$. Sediment samples in sterilized centrifuge tubes were stored at $-20{ }^{\circ} \mathrm{C}$ for quantitative PCR analysis, whereas samples in polyethylene plastic bags were firstly air dried and sieved $(2 \mathrm{~mm})$, and followed by storage at $-20{ }^{\circ} \mathrm{C}$ for endosulfan analysis (Zhao et al. 2013). Leaves samples were oven-dried at $35^{\circ} \mathrm{C}$ for $24 \mathrm{~h}$, and then stored at $-20{ }^{\circ} \mathrm{C}$ after powdered and screened through a 2 -mm pore size sieve (Zuin et al. 2003).

\section{Endosulfan extraction and determination}

Endosulfan in cultural medium and water samples were extracted using hexane-acetone $(8: 2, v / v)$, and the extraction procedure was repeated four times (Goswami et al. 2009). For 
sediment and plant samples, the soxhlet extraction method was employed to extract endosulfan according to Zhao et al. (2013).

The determination of endosulfan was performed using a Shimadzu 2014 gas

chromatograph, which was equipped with a $\mathrm{Ni}^{63}$ electron capture detector and $\mathrm{RTX}-5$ column (30 $\mathrm{m} \times 0.25 \mathrm{~mm} \mathrm{ID,} 0.25 \mu \mathrm{m}$ film thickness). An injection volume of $1 \mu \mathrm{L}$ was used (splitless mode), and the injector temperature was maintained at $260{ }^{\circ} \mathrm{C}$. The column temperature was programmed as follows: from initial temperature $120^{\circ} \mathrm{C}$ increased to $180{ }^{\circ} \mathrm{C}$ at $30{ }^{\circ} \mathrm{C} \mathrm{min}{ }^{-1}$, then ramped up to $225^{\circ} \mathrm{C}$ at $7{ }^{\circ} \mathrm{C} \min ^{-1}$ and retained for $1 \mathrm{~min}$, then to $240{ }^{\circ} \mathrm{C}$ at $5{ }^{\circ} \mathrm{C} \min ^{-1}$, maintained for $9 \mathrm{~min}$, then increased to $280{ }^{\circ} \mathrm{C}$ at $30{ }^{\circ} \mathrm{C} \mathrm{min}^{-1}$ and retained for $8 \mathrm{~min}$. The ECD was maintained at $300{ }^{\circ} \mathrm{C}$, and nitrogen $(99.99 \%$ purity) was used as carrier gas at $0.8 \mathrm{~mL} \mathrm{~min}^{-1}$.

\section{Quantitative PCR analyses}

To determine total bacteria amount in different bioremediation treatments and to explain the fate of endosulfan, total bacterial 16S rDNA genes of sediment were quantified by quantitative PCR using Roche LC-480 (USA). DNA was extracted using MOBIO PowerSandTM DNA Isolation Kit from sediment of day 6 and store at $-20{ }^{\circ} \mathrm{C}$. Eub338 and Eub518 were used as primers (Fierer et al. 2005). Reaction mixtures (20 $\mu \mathrm{L})$ contained SYBR Green Mix (15 $\mu \mathrm{L}$, Roche), primer (1 $\mu \mathrm{L}$ for each) and template DNA (3 $\mu \mathrm{L})$. Cycling was initiated with preheating for $5 \mathrm{~min}$ at $95^{\circ} \mathrm{C}$, and followed by 40 quantification cycles $\left(10 \mathrm{~s}\right.$ at $95{ }^{\circ} \mathrm{C}, 20 \mathrm{~s}$ at $55^{\circ} \mathrm{C}$ and $10 \mathrm{~s}$ at $\left.95{ }^{\circ} \mathrm{C}\right)$. The final quantitative PCR data was generated using Abs Quant/2nd Derivative Max by Roche LC-480 install. 


\section{Quality control and statistical analyses}

Erlenmeyer flasks and nutrient culture media for quantitative PCR analysis were autoclaved separately for $20 \mathrm{~min}$ at $121^{\circ} \mathrm{C}$. Glass wares for endosulfan extraction were thoroughly washed with acetones and then soaked in $5 \% \mathrm{~K}_{2} \mathrm{Cr}_{2} \mathrm{O}_{4}$ sulfuric acid solution overnight. Before use, they were cleaned with distilled water and further purged with hexane.

No contaminants showed in anhydrous sodium sulfate blanks. The correlation coefficients of the standard curves for $\alpha$-endosulfan, $\beta$-endosulfan, and PCB 209 were all above 0.9996. Uncontaminated sediment $(n=5)$ spiked with endosulfan isomers standard were extracted and examined for recovery efficiencies of $\alpha$ - and $\beta$-endosulfan. Recovery efficiencies were $81.73 \pm 8.11$ and $89.32 \pm 7.09 \%$. PCB 209 as a recovery surrogate was added prior to extraction and the recoveries were $83.45 \pm 8.20 \%$. The method detection limit (MDL) was defined as three times of the instrument detection limits (IDL) value, giving MDL values of 7.16 and $13.48 \mathrm{ng} \mathrm{L}^{-1}$ in water, 8.30 and $16.82 \mathrm{pg} \mathrm{g}^{-1}$ in sediment, 8.01 and $16.12 \mathrm{pg} \mathrm{g}^{-1}$ in plant, for $\alpha$ - and $\beta$-endosulfan, respectively.

As to the quantitative PCR analysis, plasmids containing cloned 16S rDNA gene fragments were used to generate standard curves and to relate threshold cycle (CT). Gene copy numbers revealed a linearity relationship over the plasmid $\left(R^{2} \geq 0.998\right)$. The results were calculated from three repeated experiments. Bars in the figures represent the mean \pm standard error (mean $\pm \mathrm{SE} ; n=3$ ). All the data analyses were carried out using the ORIGIN 8.0 software package. 


\section{Results and discussion}

\section{Classifications of endosulfan-degrading bacteria}

The endosulfan-degrading bacteria used in E-in were isolated from polluted soil near a pesticide factory, and the phylogenetic tree is shown in Fig. 1. Among them, three stains (ZY0, related to Alcaligenes; Z-Y1, related to Labrays; and Z-Y3, related to Serratia) were chosen for further study of bioaugmentation, which could degraded endosulfan $\left(100 \mathrm{mg} \mathrm{L}^{-1}\right)$ from sulfur-free cultural medium by 30 to $60 \%$ (Fig. 1).
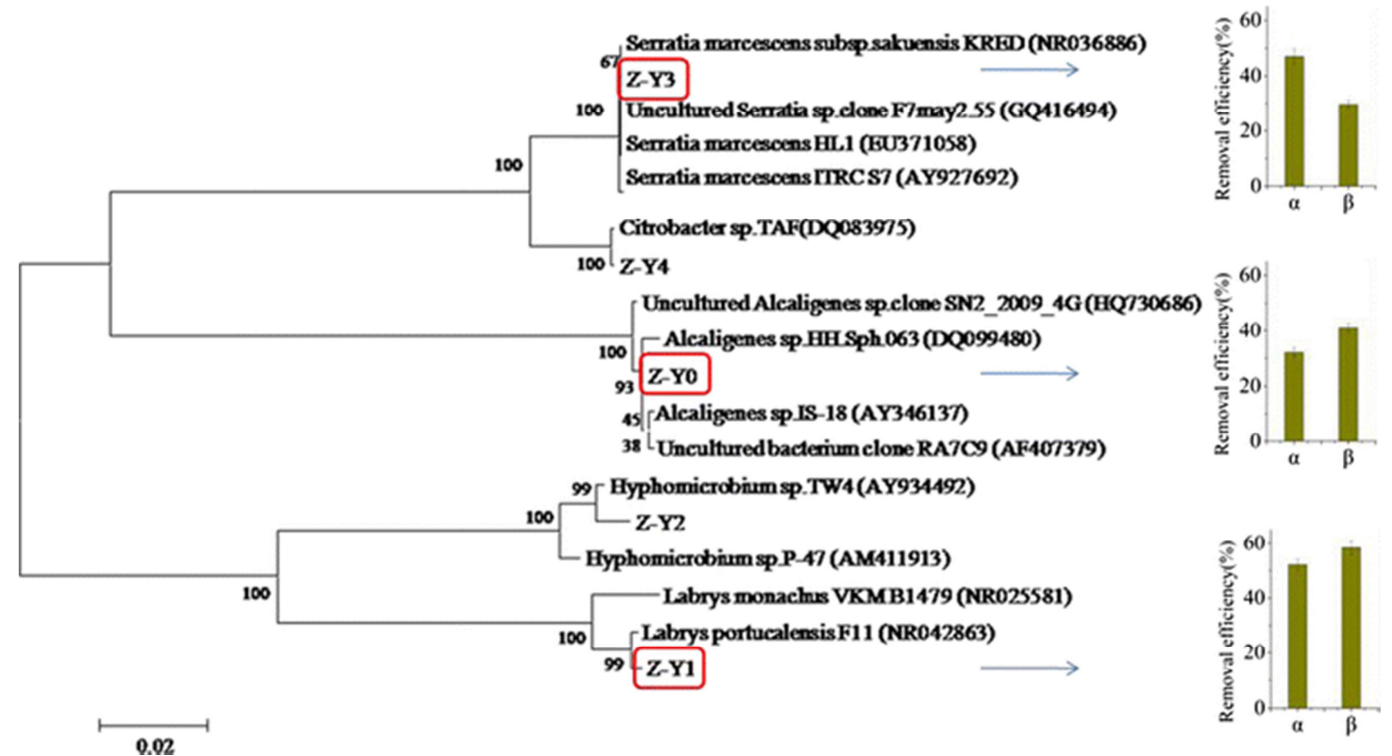

Fig. 1 Phylogenetic tree of the inoculums and their degradation abilities (stains in the red circle were the selected one for the bioremediation experiment)

\section{Process efficiency of endosulfan in constructed wetland}

In the tested constructed wetland systems, as shown in Fig. 2, endosulfan concentration dropped quickly, even in the control group. Removal efficiency in E-0 reached $73.35 \%$ on the first day and increased to $91.38 \%$ at the end of the experiment. As high-vegetationdensity regions in wetland are usually effective (Kadlec 2000), the high removal efficiency 
was reasonable in the tested constructed wetland systems (six plants per barrels; HRT, 20 days).
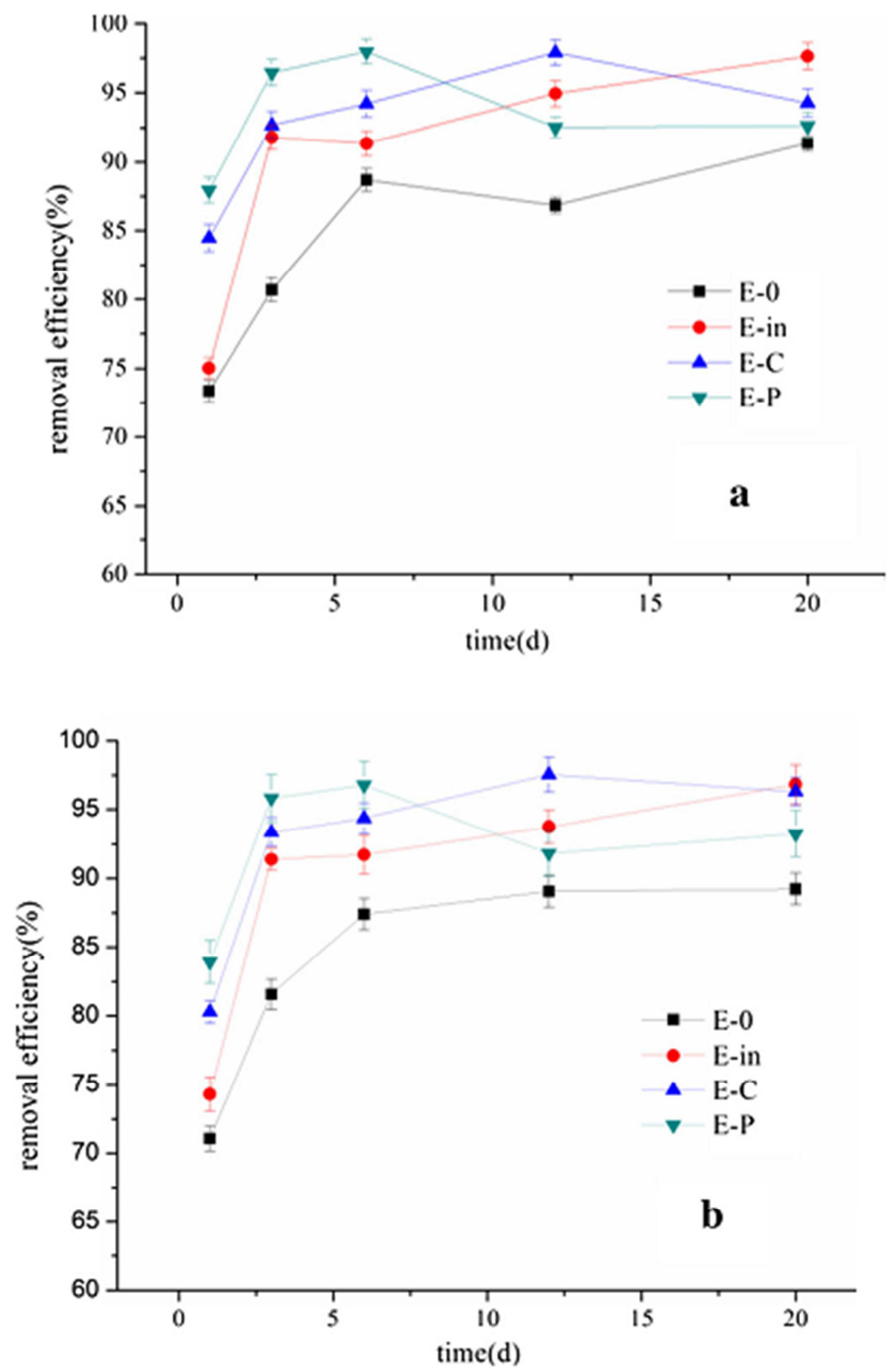

Fig. 2 Removal efficiency of endosulfan by bioaugmentation $(E$-in $)$ and biostimulation $(E-C, E-P)(\mathbf{a} \alpha$-endosulfan; $\mathbf{b} \beta$-endosulfan, $n=3)$

Concentrations of endosulfan in sediment increased rapidly with a peak shown on the 3rd day (Fig. 3). Measured peak concentration of endosulfan was the highest in the control group 
(13.45 and $3.58 \mu \mathrm{g} \mathrm{kg}^{-1}$ ), which indicated the dramatic decrease of endosulfan by bioremediation treatment ( $p<0.01$, day 3 ). Endosulfan, $\alpha$ endosulfan particularly, was greatly absorbed by P. australis (Fig. 4). Higher concentration of endosulfan in leaves was detected on the 12th day than that on the 20th day due to saddle-type absorption. While in E- $0, \alpha-$ endosulfan concentration was still rising on day 20 , which revealed a longer absorption process. 

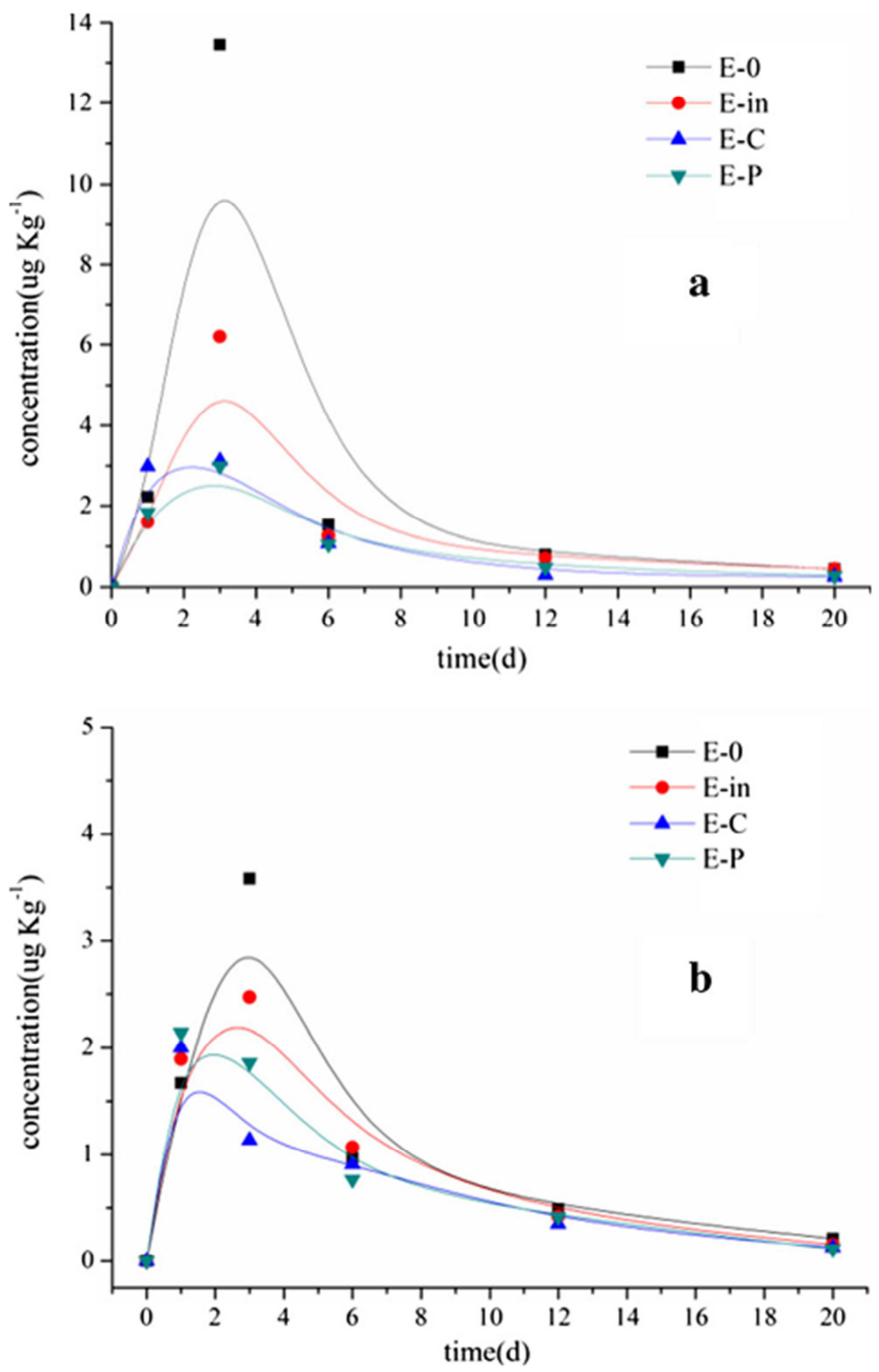

Fig. 3 Concentration of endosulfan in sediment ( $\mathbf{a} \alpha$-endosulfan; $\mathbf{b} \beta$ endosulfan, $n=3$ ) 


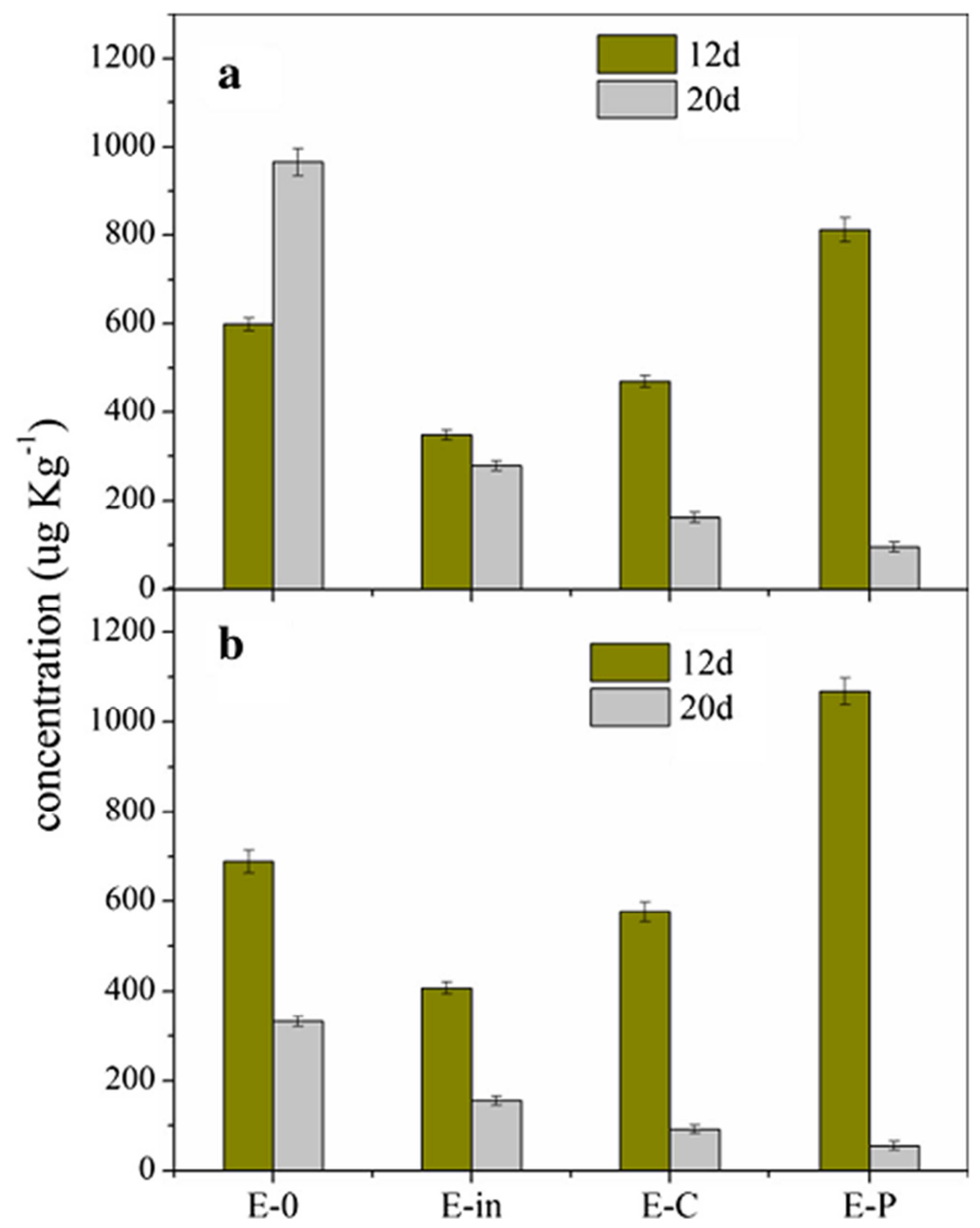

Fig. 4 Concentration of endosulfan in plants (a $\alpha$-endosulfan; $\mathbf{b} \beta$ endosulfan, $n=3$ )

Total bacterial $16 \mathrm{~S}$ rDNA genes copy numbers of sediment were quantified using quantitative PCR (Fig. 5). The abundance of total bacteria was significantly improved by bioremediation treatments, except for E-P. It was only $1.8 \times 10^{8}$ copies $\mathrm{g}^{-1}$ sediment in E-0, whereas in E-in, E-C, and E-in-C, the copy numbers reached the magnitude of $10^{9}$, and the highest copy number was shown in E-in-C $\left(1.38 \times 10^{9}\right.$ copies g sediment $\left.^{-1}\right)$. It was fairly interesting that there was only $1.65 \times 10^{8}$ copies g sediment ${ }^{-1}$ in E-P. Similarly, in E-in-P, the 
bacteria were also applied and copy numbers were only slightly improved $\left(5.40 \times 10^{8}\right.$ copies g sediment $\left.^{-1}\right)$.

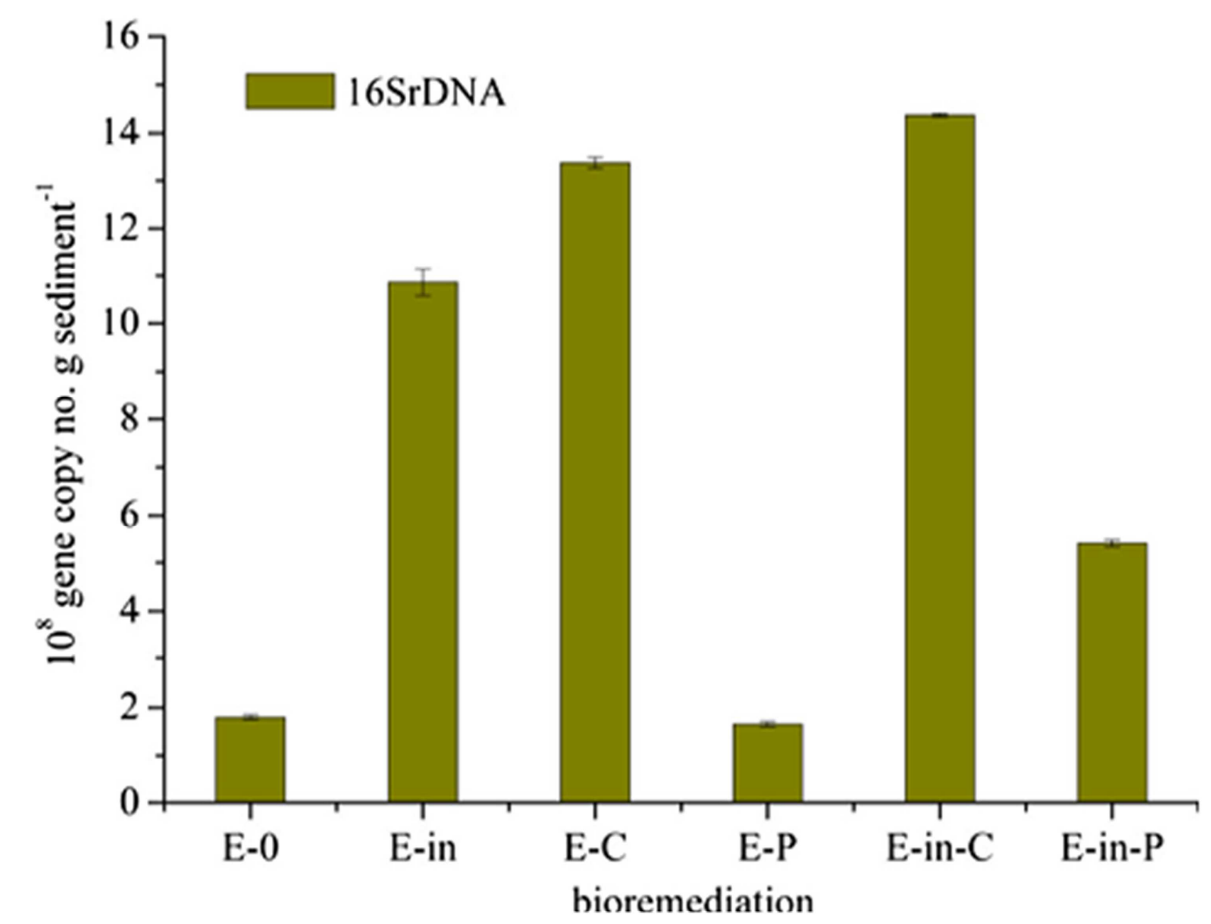

Fig. 5 Copy numbers of the total bacterial $16 \mathrm{~S}$ rDNA genes in sediments by real-time fluorescent $(n=5)$

\section{Evaluation of bioaugmentation or biostimulation treatment}

Although controversy exists in the application of bioaugmentation, positive effects on endosulfan removal were observed under bioaugmentation condition (E-in). According to Fig. 2, enhanced removal was achieved with only 1.62 and $1.89 \mu \mathrm{g} \mathrm{L}^{-1}$ of $\alpha$ - and $\beta$ endosulfan left, which was 5.91 and $7.60 \%$ higher than E-0 in removal efficiency after 20 days of application. Similar results were observed by Didier et al. (2012), that bioaugmentation could positively impact the abatement of pyrene (>95\%), compared with control (65\%) and phytoremediation (85\%). 
Adsorption of endosulfan onto sediment (Fig. 3) and absorption into plants (Fig. 4) decreased greatly in E-in. Compared with E-0, measured peak concentration in sediment was reduced by 53.92 and $31.02 \%$ for endosulfan isomers. Concentration of two isomers in leaves were 278.66 and $156.58 \mu \mathrm{g} \mathrm{kg}^{-1}$ on the 20th day, respectively, which was much lower than E-0. Dissolved and adsorbed pesticides are common forms of pesticide molecules in constructed wetland and can be absorbed onto sediment by precipitation and electrostatic attraction. As decrease of adsorbed endosulfan in sediment could either be biodegraded or desorpted from the sediment then biodegraded (Gregoire et al. 2009), the biodegradation process was dominated and probably accounted for the fate of endosulfan in E-in.

This inference was also proved by microbe quantity in the system. Quantitative PCR assays have successfully been used to monitor the fates of some introduced bacteria in complex microbial communities (Watanabe et al. 1998). By quantitative PCR, we determined that copy numbers of the total bacterial 16SrDNA genes in E-in was $9.86 \times 10^{8}$ copies $g$ sediment $^{-1}$ (Fig. 5), which was much higher than that in E-0. Although indigenous strains were enriched from soils, the effect of bioaugmentation is evident from differences in both the changes in the microbial quantities and concentration decrease of sediment and plants in E-in.

Biostimulation could encourage microorganisms to consume contaminants directly as energy and carbon sources, or indirectly by co-metabolism (Semrany et al. 2012). Sucrose and $\mathrm{KH}_{2} \mathrm{PO}_{4}$ were proved to be good accelerants in constructed wetland, which was consistent with former conclusion that organic matter and phosphorus are important factors to endosulfan distribution in soil (Zhao et al. 2013). After 20 days of treatment, residual concentrations of $\alpha$ - and $\beta$-endosulfan were 3.45 and $2.22 \mu \mathrm{g} \mathrm{L}^{-1}$ in $\mathrm{E}-\mathrm{C}$ and 4.42 and 
$4.05 \mu \mathrm{g} \mathrm{L}^{-1}$ in E-P, respectively. Compared with E-0, measured peak concentration in sediment was reduced by 76.77 and $77.75 \%$ in E-C and E-P for $\alpha$-endosulfan, and a faster adsorption was observed for $\beta$-endosulfan. While in leaves, endosulfan absorption was also reduced. However, promoted absorption of endosulfan on day 12 was exhibited in E-P and the concentration was increased to 811.64 and $1067.68 \mu \mathrm{g} \mathrm{kg}^{-1}$. It is worth noting that concentration in E-P decreased extremely on the 20th day, and concentrations of $\alpha$ - and $\beta$ isomers were only 95.66 and $55.27 \mu \mathrm{g} \mathrm{kg}^{-1}$.

As removal efficiencies, as well as microbial abundance were also accelerated in E-C (Fig. 5), whereas endosulfan concentration in plants and sediment decreased, we could get the conclusion that enhanced biodegradation accounted for endosulfan removal in E-C. This result was in accordance with the research by Goswami et al. (2009), that by adding source fungal population growth was enhanced, which lead to greater metabolism of endosulfan. In addition, high contamination removal efficiencies can be obtained under suitable $\mathrm{C} / \mathrm{N}$ ratio condition (Fan et al. 2013). It was suggested that the $\mathrm{C} / \mathrm{N}$ ratio of 14:1 (in E-C) was more favorable than 3:1 (in E-0 and E-in) to stimulate the degradation of endosulfan in constructed wetlands.

Phosphorus has been regarded as a key factor for pollutants removal. Research by Garcia-Blanco et al. (2007) proved that phosphorus was a determining variable for the degradation of PAHs. In this experiment, E-P showed the highest removal efficiency of endosulfan during the first 6 days. However the efficiency dropped after that. Interestingly, copy numbers of the total bacterial 16S rDNA genes were fairly low in E-P (Fig. 5). In the research by Beolchini et al. (2010), in which they applied $\left(\mathrm{NH}_{4}\right)_{2} \mathrm{SO}_{4}$ and $\mathrm{K}_{2} \mathrm{HPO}_{4}$ as $\mathrm{N}$ and $\mathrm{P}$ biostimulation, supplied nutrients promoted the prokaryotic growth in the early experimental 
phase, then the microbial abundances were progressively decreased. Such a decrease of microbial growth and contamination metabolism were probably related to the progressive inorganic nutrient limitation occurring over time (Perfumo et al. 2007). The pH value was in E-P higher than other treatments by $0.2-0.4$, which was an acceptable range for constructed wetland system.

Although other factors may have also contributed to the observed rate differences in E-P, the uptake by plants would be an important factor. As Collins et al. (2006) has reviewed vegetations play important roles in the global cycling of persistent organic pollutants, and the passive or active uptake of organic pollutants from soil solution into plant roots is a significant pathway. Organic pollutants in root can be subsequently transported to the plant shoot, and some pollutants will be moved to sub-stomatal tissues by the plant transpiration flux, thus they will subsequently be lost via volatilization (Farlane et al. 1990). As shown in Fig. 4, the endosulfan concentration in leaves was higher on day 12 than day 20, which was mainly because of the transportation and volatilization process. Additionally, E-P samples had much higher concentration than other treatments on day 12 , and lower concentration on day 20. Thus, we could deduce that phosphorus biostimulation increased the rate of endosulfan uptake and transport. Most importantly, endosulfan volatilization from plant leaves to the atmosphere was accelerated. Thus far, endosulfan is the most abundant organochlorine pesticide in the atmosphere, and its concentration still keeps increasing (Baek et al. 2011). Therefore, E-P revealed high air pollution potential and must be paid more attention. 
Evaluation on the combination of bioaugmentation and biostimulation

The combination of bioaugmentation and biostimulation was also tested in the current experiment (Fig. 6). Adding bacteria and sucrose (E-in-C) or bacteria and $\mathrm{KH}_{2} \mathrm{PO}_{4}(\mathrm{E}-\mathrm{in}-\mathrm{P})$ promoted endosulfan removal. $\alpha$ - and $\beta$-endosulfan removal efficiency ranged from 96.76 to $97.62 \%$, counting for 1.43 to $1.95 \mu \mathrm{g} \mathrm{L}^{-1}$ residual in water. Endosulfan concentration in sediment and plants were reduced as well. Compared with E-0, measured peak concentration on the 3rd day in sediment was reduced by 81.96 and 78.32 and 55.57 and $49.49 \%$ for $\alpha$-, $\beta$ isomer, respectively. Concentrations of the two isomers were ranged from 324.98 to $438.66 \mu \mathrm{g} \mathrm{kg}^{-1}$ on the 12 th day and from 172.54 to $367.20 \mu \mathrm{g} \mathrm{kg}^{-1}$ on the 20th day. 

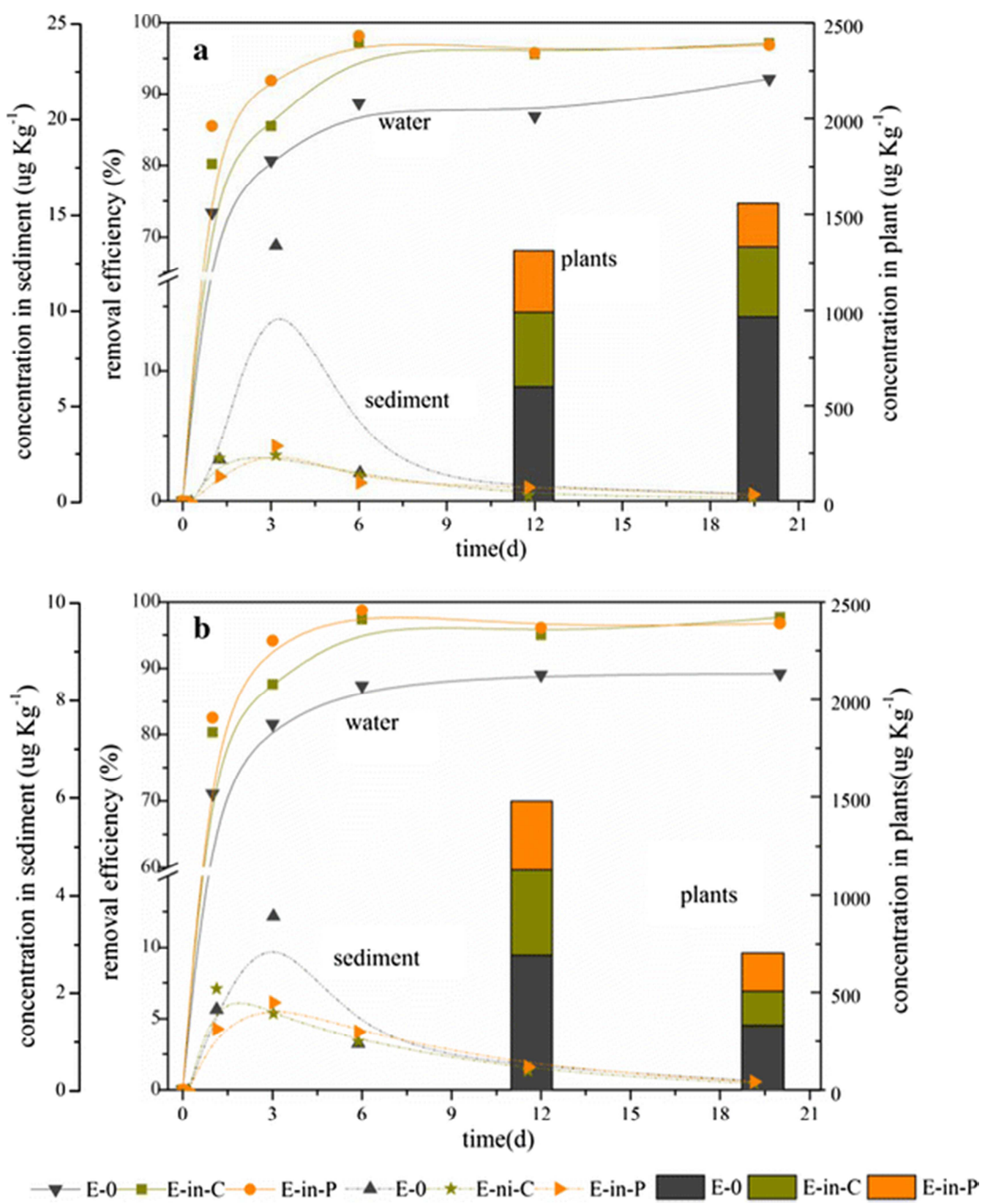

Fig. 6 Removal efficiency and concentration in sediment and plants by the combination of bioaugmentation and biostimulation ( $E$-in- $C$ and $E$-in- $P$; $\mathbf{a} \alpha$-endosulfan; $\mathbf{b} \beta$ endosulfan, $n=3$ )

Although the combined bioremediation improved the quantities of microorganisms (Fig. 5), there was not much difference in removal efficiencies when comparing with E-in and E-C. According to previous studies, a combination of bioaugmentation and biostimulation can improve the removal efficiency of organic pollutants for 0-12\% 
compared with individual treatment and different biostimulation nutrients had different removal efficiencies (Wu et al. 2011b; Taccari et al. 2012). This is probably because the different characters of the bioremediation treatment and complex reactions within the systems. Constructed wetlands can be affected by multiple factors, such as the mixed substrates, or reaction between microorganisms and the surroundings, thus affects the performance of bioremediation.

However, endosulfan concentration in plants decreased and concentration in E-in-P (Fig. 6) was much lower than that in E-P (Fig. 4). This was probably because extra phosphorous was consumed by inoculated bacteria, thereby reducing the influence of phosphorus on endosulfan uptake and transportation. Again, constructed wetland is a complex system. Therefore, further study is needed to deeply explain the key factor and the mechanism under combined bioremediation condition.

Endosulfan can be converted to endosulfan sulfate by oxidation or to endosulfan diol by hydrolysis. However, we were not able to separate the biodegradation products. According to previous studies, endosulfan sulfate has been regarded as the predominant residue in various environments, especially in aquatic systems (Leonard et al. 2001; Laabs et al. 2002). Therefore, although bioaugmentation and biostimulation were potential treatment strategies for endosulfan bioremediation in constructed wetland, several questions must be addressed in further study. In addition, endosulfan is one easy-accumulative pesticide in plants (Miglioranza et al. 2004), and it was greatly absorbed by P. australis in this study, thus the effects of bioremediation on plant absorption and its air pollution potential cannot be underestimated. Conversely, a more intensive study, focusing on the changes of wetlands characters (DO, Eh, or microbial community structure) and endosulfan degradation products, 
or a field study, is needed to deeply explain the mechanisms and optimize the performances. Furthermore, it is inferred that in rice paddy fields the transportation and volatilization of endosulfan are much severer than in constructed wetlands as this could be a serious threat to food safety.

\section{Conclusions}

This study confirmed bioremediation was effective strategy for constructed wetlands contaminated with endosulfan. Using bioremediation, removal efficiencies of endosulfan were enhanced. Biodegradation was probably promoted by bioaugmentation and biostimulation with sucrose, and endosulfan concentration in plants and sediment decreased. Adding $\mathrm{KH}_{2} \mathrm{PO}_{4}$ could increase endosulfan absorption by plants. As endosulfan can be released into the atmosphere by volatilization from leaves, reducing endosulfan concentration in plants could has significant meaning in air pollution control and needs further investigation.

\section{Acknowledgments}

The authors gratefully acknowledge financial support by the National Science Foundation of China (21007032), National Water Special Project (2012ZX07203-004), Independent Innovation Foundation of Shandong University (2012JC029), and Natural Science Foundation for Distinguished Young Scholars of Shandong province (JQ201216).

\section{References}

Abou-Shanab RA, Ghanem K, Ghanem N, Al-Kolaibe A (2008) The role of bacteria on heavy-metal extraction and uptake by plants growing on multi-metal-contaminated soils. World J Microbiol Biotechnol 24:253-262 
Baek SY, Choi SD, Chang YS (2011) Three-year atmospheric monitoring of organochlorine pesticides and polychlorinated biphenyls in Polar Regions and the South Pacific. Environ Sci Technol 45:4475-4482

Beolchini F, Rocchetti L, Regoli F, Dell'Anno A (2010) Bioremediation of marine sediments contaminated by hydrocarbons: experimental analysis and kinetic modeling. J Hazard Mater 182:403-407

Cheng S, Vidakovic-Cifrek Ž, Grosse W, Karrenbrock F (2002) Xenobiotics removal from polluted water by a multifunctional constructed wetland. Chemosphere 48:415-418

Collins C, Fryer M, Grosso A (2006) Plant uptake of non-ionic organic chemicals. Environ Sci Technol 40:45-52

Didier T, Philippe LG, Sonia H, Amar B, Claudia MC, Marielle DI, Jairo F (2012) Prospects of Miscanthus x giganteus for PAH phytoremediation: a microcosm study. Ind Crops Prod $36: 276-281$

Fan JL, Wang WG, Zhang B, Guo YY, Ngo HH, Guo WS, Wu HM (2013) Nitrogen removal in intermittently aerated vertical flow constructed wetlands: impact of influent COD/N ratios. Bioresour Technol 143:461-466

Farlane CM, Pfleeger T, Fletcher J (1990) Effect, uptake and disposition of nitrobenzene in several terrestrial plants. Environ Toxicol Chem 9:513-520

Fierer N, Jackso JA, Vilgalys R, Jackson RB (2005) Assessment of soil microbial community structure by use of taxon-specific quantitative PCR assays. Appl Environ Microbiol $71: 4117-4120$

Filler DM, Van Stempvoort DR, Leigh MB (2009) Remediation of frozen ground contaminated with petroleum hydrocarbons: feasibility and limits, in Permafrost soils. Heidelberg, Berlin, pp 279-301 
Garcia-Blanco S, Venosa AD, Suidan MT, Lee K, Cobanli S, Haines JR (2007)

Biostimulation for the treatment of an oil-contaminated coastal salt marsh. Biodegradation $18: 1-15$

Goswami S, Vig K, Singh DK (2009) Biodegradation of $\alpha$ and $\beta$ endosulfan by Aspergillus sydoni. Chemosphere 75:883-888

Gregoire C, Elsaesser D, Huguenot D, Lange J, Lebeau T, Merli A, Mose R, Passe-port E, Payraudeau S, Schutz T, Schulz R, Tapia-Padilla G, Tournebize J, Trevisan M, Wanko A (2009) Mitigation of agricultural nonpoint-source pesticide pollution in artificial wetland ecosystems. Environ Chem Lett 7:205-231

Jia HL, Liu LY, Sun YQ, Sun B, Wang DG, Su YH, Kannan K, Li YF (2010) Monitoring and modeling endosulfan in Chinese surface soil. Environ Sci Technol 44:9279-9284

Kadlec RH (2000) The inadequacy of first-order treatment wetland models. Ecol Eng $15: 105-119$

Kalyani SS, Sharma J, Singh S, Dureja PL (2009) Enrichment and isolation of endosulfandegrading microorganism from tropical acid soil. J Environ Sci Health B 44:663-672

Laabs V, Amelung W, Pinto AA, Wantzen M, da Silva CJ, Zech W (2002) Pesticides in surface water, sediment, and rainfall of the northeastern Pantanal basin, Brazil. J Environ Qual 31:1636-1648

Leonard AW, Hyne RV, Lim RP, Leigh KA, Le J, Beckett R (2001) Fate and toxicity of endosulfan in Namoi River water and bottom sediment. J Environ Qual 30:750-759

Miglioranza KSB, de Moreno JEA, Moreno VJ (2004) Organochlorine pesticides sequestered in the aquatic macrophyte Schoenoplectus californicus(C.A. Meyer) Soják from a shallow lake in Argentina. Water Res 38:1765-1772

Perfumo A, Banat IM, Marchant R, Vezzulli L (2007) Thermally enhanced approaches for bioremediation of hydrocarbon-contaminated soils. Chemosphere 66:179-184 
Prochaska CA, Zouboulis AI (2006) Removal of phosphates by pilot vertical-flow constructed wetlands using a mixture of sand and dolomite as substrate. Ecol Eng 26:293303

Santos HF, Carmo FL, Paes JE, Rosado AS, Peixoto RS (2011) Bioremediation of mangroves impacted by petroleum. Water Air Soil Pollut 216:329-350

Semrany S, Favier L, Djelal H, Taha S, Amrane A (2012) Bioaugmentation: possible solution in the treatment of Bio-Refractory Organic Compounds (Bio-ROCs). Biochem Eng J 69:75-86

Silva MH, Beauvais SL (2010) Human health risk assessment of endosulfan. I: toxicology and hazard identification. Regul Toxicol Pharmacol 56:4-17

Taccari M, Milanovic V, Comitini F, Casucci C, Ciani M (2012) Effects of biostimulation and bioaugmentation on diesel removal and bacterial community. Int Biodeterior Biodegrad 66:39-46

UNEP/POPS/POPRC.6/13/Add.1 (2010) Report of the Persistent Organic Pollutants Review Committee on the work of its sixth meeting. Sixth meeting of Persistent Organic Pollutants Review Committee, Geneva, 11-15 October

Watanabe K, Yamamoto S, Hino S, Harayama S (1998) Population dynamics of phenoldegrading bacteria in activated sludge determined by gyrB-targeted quantitative PCR. Appl Environ Microbiol 64:1203-1209

Wu H, Zhang J, Li P, Zhang J, Xie H, Zhang B (2011a) Nutrient removal in constructed microcosm wetlands for treating polluted river water in northern China. Ecol Eng 37:560568

Wu Z, Dong H, Zou L, Lu D, Liu Z (2011b) Enriched microbial community in bioaugmentation of petroleum-contaminated soil in the presence of wheat straw. Appl Biochem Biotechnol 164:1071-1082 
Wu SQ, Chang JJ, Dai Y, Wu ZB, Liang W (2013) Treatment performance and microorganism community structure of integrated vertical-flow constructed wetland plots for domestic wastewater. Environ Sci Pollut Res 20:3789-3798

Yu L, Peng D, Ren Y (2011) Protozoan predation on nitrification performance and microbial community during bioaugmentation. Bioresour Technol 102:10855-10860

Zhang A, Fang L, Wang J, Liu W, Yuan H, Jantunen L, Li YF (2012) Residues of currently and never used organochlorine pesticides in agricultural soils from Zhejiang Province, China. J Agric Food Chem 60:2982-2988

Zhao CC, Xie HJ, Zhang J, Xu JT, Liang S (2013) Spatial distribution of organochlorine pesticides (OCPs) and effect of soil characters: a case study of a pesticide producing factory. Chemosphere 90:2381-2387

Zuin VG, Yariwake JH, Bicchi C (2003) Fast supercritical fluid extraction and highresolution gas chromatography with electron-capture and flame photometric detection for multiresidue screening of organochlorine and organophosphorus pesticides in Brazil's medicinal plants. J Chromatogr A 985:159-166 